\section{進行消化器癌における大腰筋面積の変化と予後 に関する検討}

森 直治、東口 高志、伊藤 彰博、都築 則正、 阿波宏子

藤田保健衛生大学医学部外科・緩和医療学講座
$0-2-2$

食道癌手術症例における術前サルコペニア評価 と術後短期成績との関連についての検討

福田 泰也、山本 和義、西川 和宏、平尾 素宏、 原口 直紹、三宅 正和、浅岡 忠史、大宮 英泰、 宮本 敦史、池田 正孝、高見 康二、中森 正二、 関本 貢嗣 独立行政法人国立病院機構大阪医療セン夕ー

【背景】サルコペニアは、全身性に認める筋肉量・ 筋力低下であり、癌患者においても 2 次性にサルコ ペニアが生じることがあり、近年注目されている概 念である。特に高齢者の多い食道癌患者の中にはサ ルコペニアの合併率が高く、治療成績に悪影響を与 えていることが予想される。

【対象と方法】対象は、2012 年 8 月から 2014 年 1 月までに当科で食道癌に対して根治術を施行した 20 例。6 5 歳以上を対象として、EWGSOP の基準 に従って、術前に歩行速度 $(\mathrm{m} / \mathrm{s})$ 、握力 $(\mathrm{kg})$ 、 InBody720 (Biospace 社) を用いたSMI（骨格筋 量／身長 2) 值からサルコペニア有無を判定した。 サルコペニア症例と高齢非サルコペニア + 同時期に 行った 65 歳未満の症例で 2 群に分け、その背景お よび術後短期成績との関連について検討した。

【結果】全 20 例の平均年齢は $64.7 \pm 10.3$ 歳、男 18 例、 女 2 例。6 65 歳以上の症例は 11 症例で、このうちサ

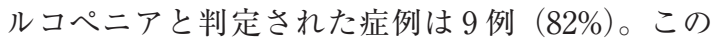
9 例（サルコペニア有群）と残り 11 例（高齢非サ ルコペニア症例 2 例 +65 歳未満の症例 9 例 : サル コペニア無群）の背景では、無群で進行癌が多かっ た が (pStage $1,2 / 3,4: 6 / 2$ vs $3 / 8 \mathrm{p}=.02$ )、 ASA-PS は有群で悪く (1,2/3:5/4 vs $11 / 0 \mathrm{p}=$ .01）、術前呼吸機能も有群で有意に悪かった（肺活 量 : $2.66 \pm 0.51$ vs $4.05 \pm 0.49 \mathrm{~L} \mathrm{p}<.001$ 、一秒量 : $2.47 \pm 0.45$ vs $3.53 \pm 0.60 \mathrm{~L} \mathrm{p}=.002)$ 。その他 $\mathrm{BMI}$ $\left(\mathrm{kg} / \mathrm{m}^{2}\right)$ 、術前血清 $\mathrm{Hb}$ 、Alb 值、術前湶取カロリー $(\mathrm{kcal} / \mathrm{IBW}(\mathrm{Kg}))$ 、摂取蛋白量 $(\mathrm{g} / \mathrm{IBW}(\mathrm{Kg}))$ には有意差を認めなかった。術後合併症については、 Clavien Dindo 分類で Grade3 以上の症例が有群で 有意に多く (88.9 vs $36.3 \%$ p = .02)、そのうち無気 肺、肺炎などの呼吸器合併症も有群で有意に多かっ た（66.7 vs 9.1\% p = .005）。両群で手術関連死亡例 は認めなかった。

【結語】 65 歳以上の食道癌手術症例では、高率にサ ルコペニアを合併しており、術前 ASA-PS、呼吸 器機能が悪く、重篤な術後合併症率が有意に高く、 特に呼吸器合併症ではその差が顕著であった。術前 にサルコペニアと診断された食道癌手術症例に対し ては、呼吸器リハビリやエクササイズの介入を行う ことが望ましいと考えられた。 
高齢胃癌胃切除患者におけるサルコペニアの術 後合併症発生に与える影響

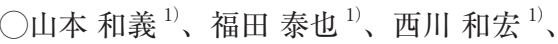

平尾 素宏 ${ }^{1)}$ 、中山 環 ${ }^{2)}$ 、森住 蘭 ${ }^{2}$ 、永妻 佑季子 ${ }^{2)}$ 、 谷川 清 $^{2)}$ 、原口 直紹 ${ }^{1)}$ 、三宅 正和 ${ }^{1)}$ 、浅岡 忠史 ${ }^{1)}$ 、

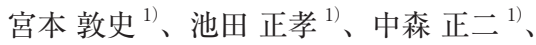

関本 貢嗣 ${ }^{1)}$

1) 国立病院機構大阪医療セン夕ー外科

2）国立病院機構大阪医療センター栄養管理室

【背景】サルコペニア（Sarcopenia）は、「加齢によ る筋肉量や筋力の低下」と定義される。特に胃癌患 者の中には癌による異化光進や食事摂取不良のため に低栄養に陥っている症例も多いため、術前からサ ルコペニアを合併している症例が多く、ADLの低 下や術後合併症の増加などにより治療成績に悪影響 を及ぼしている可能性が示唆される。

【対象と方法】 2012 年 7 月〜 2014 年 2 月の期間で、 当科にて行った 65 歳以上の高齢胃がん手術症例 73 例から胃悪性リンパ腫 1 例、胃 GIST high risk2 例、 胃空腸バイパス術を施行した 1 例を除いた全 69 例 を対象に、サルコペニア合併率、サルコペニア症例 と非サルコペニア症例との間で術前栄養摂取状況、

背景因子、術後短期治療成績について Retrospective に検討した。術後合併症は Clavien-Dindo 分類を用 いて Gradingを行なった。

【結果】高齢者胃癌胃切除症例全 69 例中 38 例 （55.1\%）にサルコペニアを認めた。術前の食物摂取 頻度調査（FFQg）を用いた術前摂取栄養量の比較 では、サルコペニア群で非サルコペニア群に比べて 有意に摂取エネルギー量が少なく（25.3 $\pm 4.5 \mathrm{vs}$ $28.9 \pm 5.4 \mathrm{kcal} / \mathrm{IBWkg} 、 \mathrm{p}=0.0040$ )、摂取タンパク 質量が少なかった $(0.94 \pm 0.18$ vs $1.08 \pm 0.20 \mathrm{~g} / \mathrm{IB}-$ Wkg、 p = 0.0030)。術後全合併症発生率は両群で 差を認めなかったが (50.0\% vs $54.8 \%) 、 C l a v i e n-$ Dindo 分類の Grade3 以上の合併症発生率はサルコ ペニア群で有意に高かった（23.7 vs 6.5\%、p = 0.043）。 Grade3 以上の合併症発生に関する因子をロジス ティック回帰分析にて多変量解析したところ、サル コペニア有りが独立した危険因子であった（OR 5.86、95\%CI 1.06-51.65、 $\mathrm{p}=0.042)$ 。

【考察】高齢胃癌胃切除患者の $55.1 \%$ にサルコペニ アを認め、Grade3 以上の術後合併症発生との関連 が示された。胃癌サルコペニア症例では有意に食事 摂取エネルギー量、タンパク質量が少なく、サルコ ペニアを合併した胃癌手術症例に対しては、適切な 栄養介入やエクササイズが重篤な合併症を回避する うえで有用である可能性があると考えた。

\section{胃切除術後 1 年目の体重減少と周術期因子と} の関連の検討

$\bigcirc$ 村上 剛平 ${ }^{1)}$ 、瀧口 修司 ${ }^{1)}$ 、高橋 剛 ${ }^{1)}$ 、黑川 幸典 ${ }^{1)}$ 、 中島 清一 ${ }^{1)}$ 、今村 博司 ${ }^{2)}$ 、平尾 素宏 ${ }^{3)}$ 、 藤田 淳也 ${ }^{4)}$ 、矢野 雅彦 ${ }^{5)}$ 、森 正樹 ${ }^{1)}$ 、 土岐 祐一郎 ${ }^{11}$
1) 大阪大学医学部大学院消化器外科
2) 市立堺病院
3）国立病院大阪医療センター
4) NTT 西日本大阪病院
5）大阪府立成人病センター

【背景・目的】胃癌術後の体重減少は、術後の患者 の栄養状態や生活の質に関連する重要な指標であり、 また術後補助化学療法の継続性との関連も報告され ている。早期胃癌術後の予後は良好であり、術後の QOL の維持が重要となる。胃癌術後の患者の愁訴 に体重減少が多く、体重減少の抑制は術後 QOL の 維持に重要と考えられる。本研究では、胃癌術後 1 年目の体重減少に関わる周術期因子の探索を目的に 検討を行った。

【対象】対象は 2005 年〜2008 年に当院を含む関連 施設で早期胃癌にて幽門側胃切除術を施行した 167

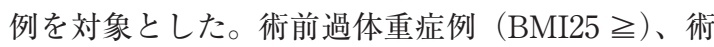
後化学療法施行症例は除外した。

【結果】術後の体重の推移は、術前体重を $100 \%$ と して、退院時 $93.9 \pm 3.2 \%$ 、術後 3 力月 $91.3 \pm 8.4 \%$ 、 術後 6 力月 $90.4 \pm 9.1 \%$ 、術後 1 年 $91.6 \pm 6.1 \%$ で あった。術後 1 年の時点で $10 \%$ 以上の体重減少を 認める症例を体重減少群として周術期の要因を検討 した。単変量解析では性別、年齢、再建方法 (B1 or RY)、術中出血量、手術時間、術後の食事開始日、 術後の合併症の有無、合併症による絶食の有無に有 意差は認めず、退院時の体重減少率 $10 \%$ 以上、術 前 BMI（BMI24 以上）に有意差を認めた。多変量 解析でも、退院時の体重減少率 $10 \%$ 以上、術前 BMI（BMI24 以上）が独立した因子であった。

【まとめ】胃癌術後 1 年の体重減少と退院時の体重 減少に相関を認めたことから、術後の入院中の体重 減少の抑制が、長期的な体重減少の抑制につながる 可能性が示唆された。入院中の体重減少を抑制する ためにどのような介入が効果的であるかが今後の検 討課題と考えられた。 